\title{
DEVELOPMENT OF SALES APPLICATION OF PREPAID ELECTRICITY VOUCHER BASED ON ANDROID PLATFORM USING QUICK RESPONSE CODE (QR CODE)
}

\author{
Ricky Akbar ${ }^{1)}$, Husnil Kamil' ${ }^{2}$ \\ ${ }^{\mathrm{I}, 2)}$ Information System Department, Information Technology Faculty, Andalas University \\ Campus of Universitas Andalas, Limau Manis, Padang \\ Telp: (0751) 9824667 \\ e-mail: rickyakbar1984@gmail.com, husnil.k@gmail.com
}

\begin{abstract}
Perusahaan Listrik Negara (PLN) has implemented a smart electricity system or prepaid electricity. The customers pay the electricity voucher first before use the electricity. The token contained in electricity voucher that has been purchased by the customer is inserted into the Meter Prabayar (MPB) installed in the location of customers. When a customer purchases a voucher, it will get a receipt that contains all of the customer's identity and the 20-digit of voucher code (token)to be entered into MPB as a substitute for electrical energy credit. Receipts obtained by the customer is certainly vulnerable to loss, or hijacked by unresponsible parties. In this study, authors designed and develop an android based application by utilizing $Q R$ code technology as a replacement for the receipt of prepaid electricity credit which contains the identity of the customer and the 20-digit voucher code. The application is developed by implemented waterfall methodology. The implementation process of the waterfall methods used, are (1) analysis of functional requirement of the system by conducting a preliminary study and data collection based on field studies and literature, (2) system design by using UML diagrams and Business Process Model Notation (BPMN) and Entity Relationship diagram (ERD), (3) design implementation by using OOP (Object Oriented programming) technique. Web application is developed by using laravel PHP framework and database MySQL while mobile application is developed by using B4A (4) developed system is tested by using blackbox method testing. Final result of this research is a Web and mobile applications for the sale of electricityvoucher by QR Code technology.
\end{abstract}

Keywords: Prepaid Electricity, QR Code, Electricity Voucher, OOP, MVC, Mobile Application.

\section{INTRODUCTION}

PT. PLN has implemented a new system on how to pay for the electricity usage by utilizing smart prepaid electricity system (Smart Electricity). In this prepaid electricity system, customer buy the voucher first for the electricity to be comsumed. The token contained voucher had been purchased, entered into Meter Prabayar (MPB) which is installed on customer location. Meter Prabayar (MPB) provides information on the amount of electrical energy $(\mathrm{kWh})$ left which can be used by customer. The amount of electricl energy on Meter Prabayar can be added whenever the customer needs to. Thus, customers can easily optimize and control electricity consumption and also set their own schedule to purchage the electricity credit and also the amount of electricity purchases. By using Smart Electricity system, customers do not need to deal with metering which is usually 


\section{JURNAL INFORMATIKA Vol. 11, No. 2 Juli 2017}

done every month, and not tied to the payment schedule of monthly electricity bill. The price of electricity usage using prepaid electricity system compared to postpaid electric system is equal. This calculation is already standardized and the price of prepaid electricity is set and issued in Tarif Dasar Listrik (TDL) 2010 by the minister of Energy and Mineral Resources via requlation No. 07 year 2010. By using this system, behavior of the consumer regarding electricity usage will determine frugal or extravagant electricity usage. Similar to the phone, the person will tend to skimp prepaid phone and postpaid phone to be wasteful because less restrained [1].

Obtianing prepaid electricity voucher can be done through the nearest PLN, Post Office official Bank which is appointed by PLN to sell prepaid electricity vocher, ATM, or sales outlet of electronic phone voucher that have deal the bank in to sell this prepaid electricity voucher. When customers make a purchase prepaid electrivity voucher, the customer will recive a receipt that contains a number of utility bills, along with other identities, as well as the 20-digit voucher code. This 20-digit voucher code will be entered into Meter Prabayar (MPB) and converted into electricity energy credit. The receipts received by customers made of paper so it would be vulnerable to loss and also 20-digit voucher number and identity of the customer listed on the receipt could be hijacked by unresponsible parties.

Based on previous explanation, it is clear that there is a problemin electricity voucher purchase system. To solve this problem, we need a special application that can be a replacement of receipt which the identity and the 20-digit voucher code need to become a symbol or a secret code. So in this study the authors designed an android application by utilizing Quick Response Code (QR Code) to replace a receipt containing the identity of the customer and 20-digit code digits in earlier receipt. QR Code need to be set so it can only be used by the customer that bought the electricity voucher, and cannot be used by other parties. The QR Code utilization has also been investigated by Nugraha and Munir (2011) on Konferensi Nasionnal Informatika di Bandung [2]. Their research is making a QR Code from data in form of image. While in this research QR Code is made form data in the form of text. This application is based on Android and can be run through the existing smartphone. Through this application, customers are able to buy electricity voucher safely and secure.

\section{QUICK RESPONSE CODE (QR CODE)}

QR Code is a two-dimensional image in the form of a matrix that can be used to store data on it. QR Code is an evolution of the traditional barcode. Barcode is a labelling symbol of the real object made of sticks pattern in black and white to make it easier to be recognized by the computer [3]. While barcode is one-dimensional, QR Code is two-dimensional image. An example of a QR Code can be seen in figure 1.

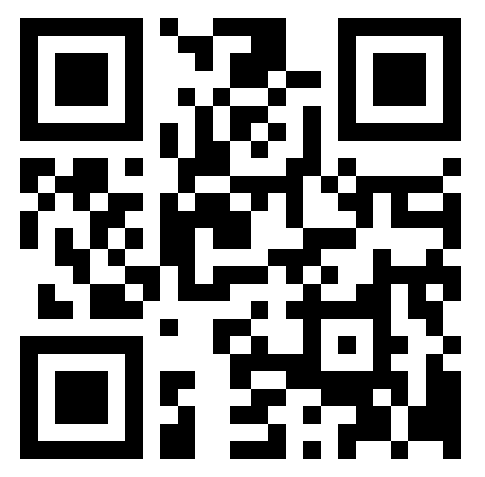




\section{JURNAL INFORMATIKA Vol. 11, No. 2 Juli 2017}

Figure 1. QR Code example [3]

A detailed description of the QR Code image example above can be seen from the picture 2 .
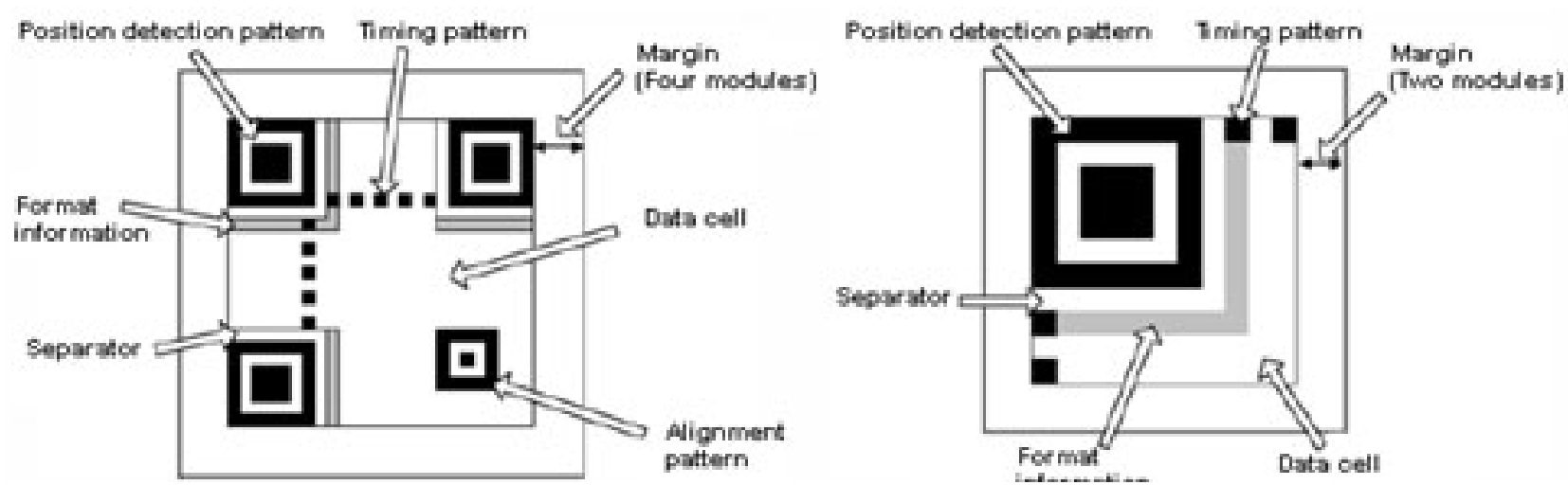

Figure 2. Detail of QR Code [4]

From Figure 2 can be explained in detail the parts of the QR Code as follows [4]:

a. Position detection patterns: The position detection patterns placed at three corners of the QR code, position of the QR code is detected by the position detection patterns that enables high speed read and can be read from any direction.

b. Margin: This is the empty area around the QR code and requires a margin of four modules.

c. Timing pattern: Arranged white module and black module which determine the coordinates. The time pattern is placed between two position detection patterns in a $\mathrm{QR}$ code.

d. Format Information: The format information is read first when the code is translated QR Code generation procedure of a text can be described by the flow diagram in Figure 3.

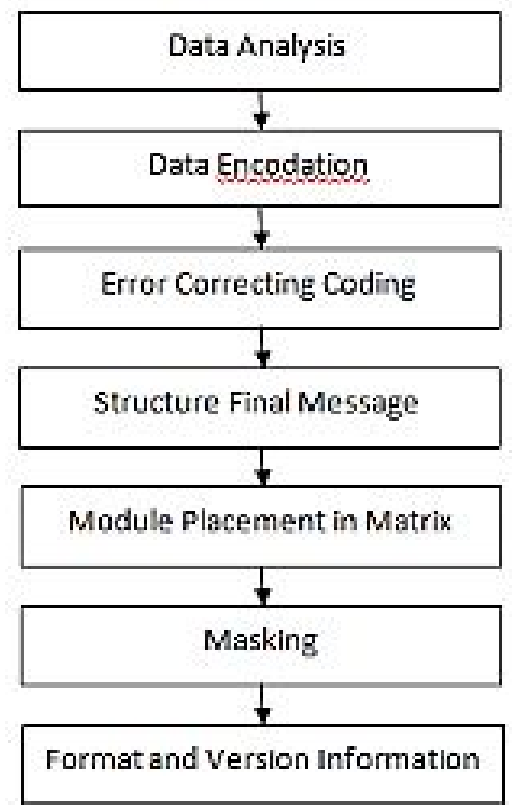

Figure 3. Diagram Alir Proses Pembangkitan QR Code [2] 


\section{JURNAL INFORMATIKA Vol. 11, No. 2 Juli 2017}

Steps to read the QR Code into the original text is opposite to the generation of QR Code. In general, the reading procedure QR Code can be explained by the flowchart in Figure 4

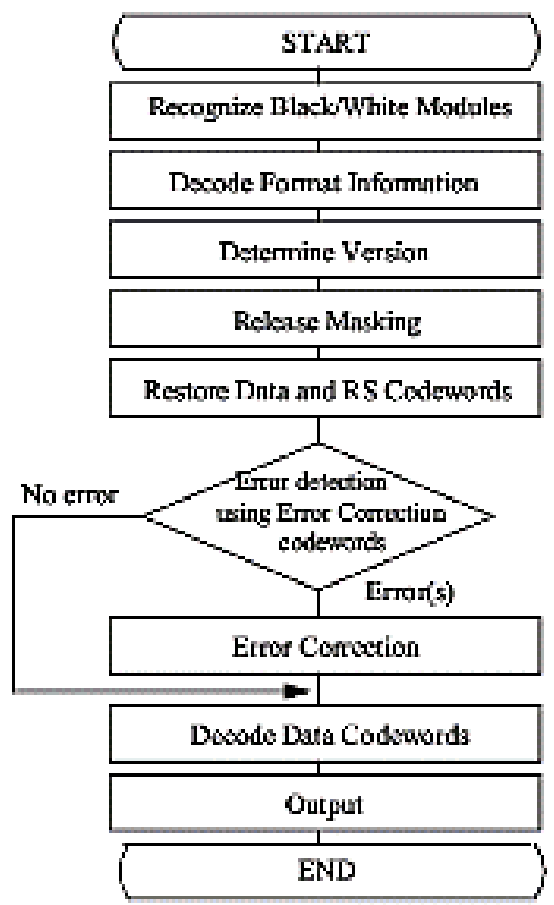

Figure 4. Flowchart of reading QR Code [2]

\section{RESEARCH METHODOLOGY}

This research is development of an information system for a company. Output of this research would be software. Thus the methodology used in this research adopt SDLC methodology (Software Development Life Cycle). SDLC is a software development life cycle that involve a set of procedures, steps, tools used in building software. In general, SDLC is consist of five stages, that is requirement analysis, design, implementation, testing and maintenance of software [5]. The purpose of this SDLC is to get high quality software, in accordance with the allocation of costs and time desired.

SDLC is implemented through software development process model. There are several variants of the software development process models, one of them is the waterfall model. In waterfall model, each process is done stages by stages [5]. Waterfall development process models can be seen in Figure 5 


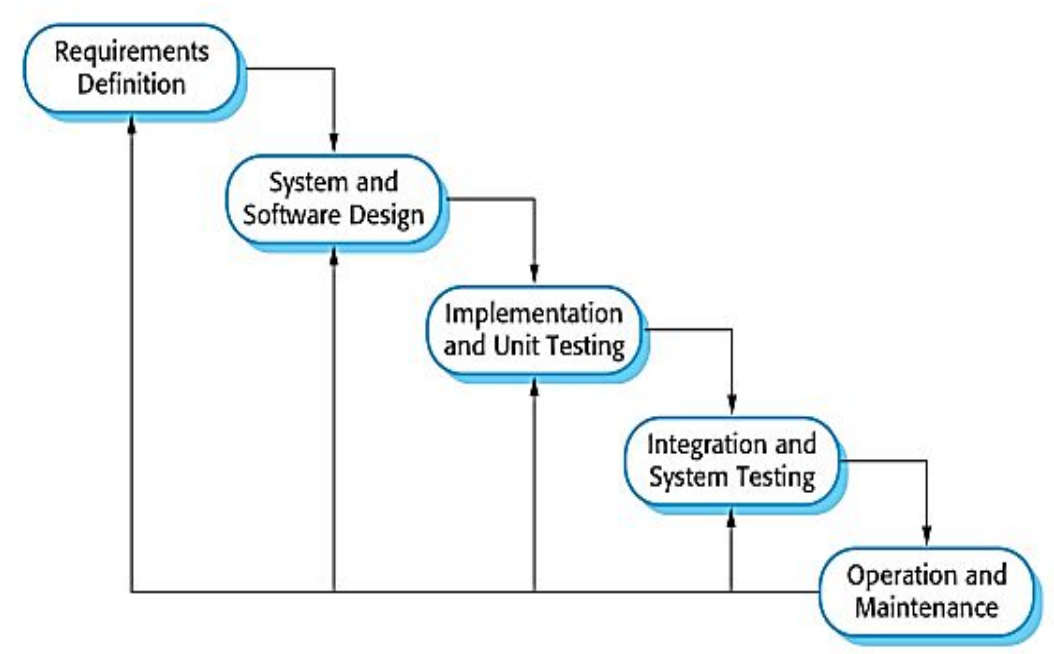

Figure 5. Waterfall model of software development cycle [5]

\section{ANALYSIS AND DESIGN}

This section describes the analysis of functional requirement of the system based on the results of field observations. This section also describes about design of the system based on the analysis of the data obtained. The process of system analysis modelled by using Business Process Modeling Notation (BPMN) and use case diagrams, as well as system design stage by Entity Relational Diagram (ERD) and application architecture.

\subsection{System Analysis}

System analysis is a stage to analyze the current system and elaborate functional requirement of designed system. Programming concept used is Object Oriented Programming (OOP) so that the modeling tools used is UML (Unified Modeling Language). Tools used to analyze current system is the Business Process Model Notation (BPMN) and Use Case Diagram along with use case scenarios. Thoe modeling is considered sufficient to describe the functional of application.

\subsubsection{BPMN of Prepaid Electric Voucher Sales}

The sales process is a business process that occurs in the service provider of prepaid electricity voucher sales. These sales are usually found on the counters PLN, POS, Bank, ATM or other electronic Voucher sales outlets. The following is sales process of prepaid electricity voucher:

a. Customer comes to buy prepaid electricity voucher outlet and the outlet operator will ask or inquire customer's electricity account number.

b. The outlet operator will check the electricity account number on the application system which integrated directly with the database PLN. If customer's electricity account number is valid, the application will display all of the customer's identity.

c. Outlet operators will entry prepaid electricity voucher nominal amount that requested by customer.

d. If all the data had been entered and completed, the outlet operator will printe the receipt in a form of QR Code Stroom. Customer will scan the QR Code with a special application design to generate $\mathrm{QR}$ Code into data the 
subscriber's identity number and 20-digit voucher number that will be entered to the MPB.

Based on the sales process prepaid electricity voucher, can be made BPMN of the process as seen in Figure 6.

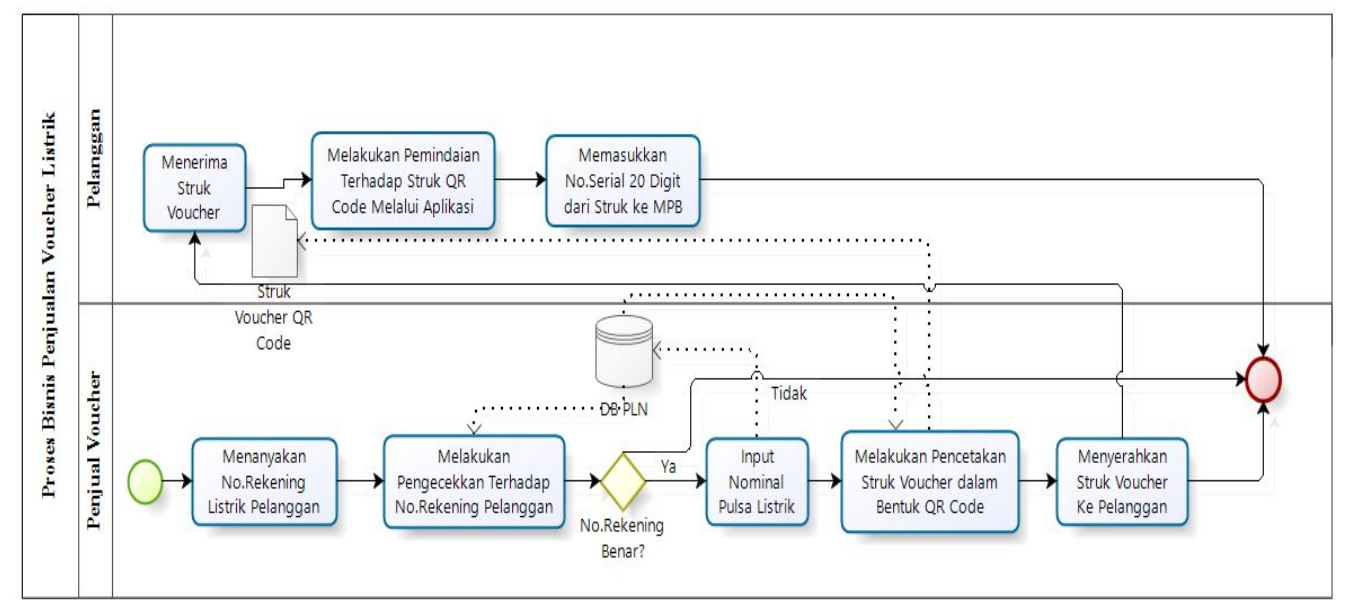

Figure 6. BPMN of Prepaid Electricity Voucher sales

\subsubsection{Use Case Diagram}

Use Case Diagram is a diagram to visualize the functional requirements of a system. Use Case describes a typical interaction among the users of the system with the system itself, by giving a narration of how the system is used. Use Case diagram which the actors are using the use case, which use case include another use case and the relationship between the actor and the use case [6]. Based on analysis of sales process, there are 2 actors involved in the system namely outlet operators and customers. The two actors do some activities, that are logged into the system, input customer data, recharge prepaid electricity voucher, print out receipts, manage sales report prepaid electricity voucher, scan the QR Code with Mobile Application, entry scanned 20-digit voucher code to MPB. Use Case Diagram of prepaid electricity voucher application can be seen in Figure 7. 


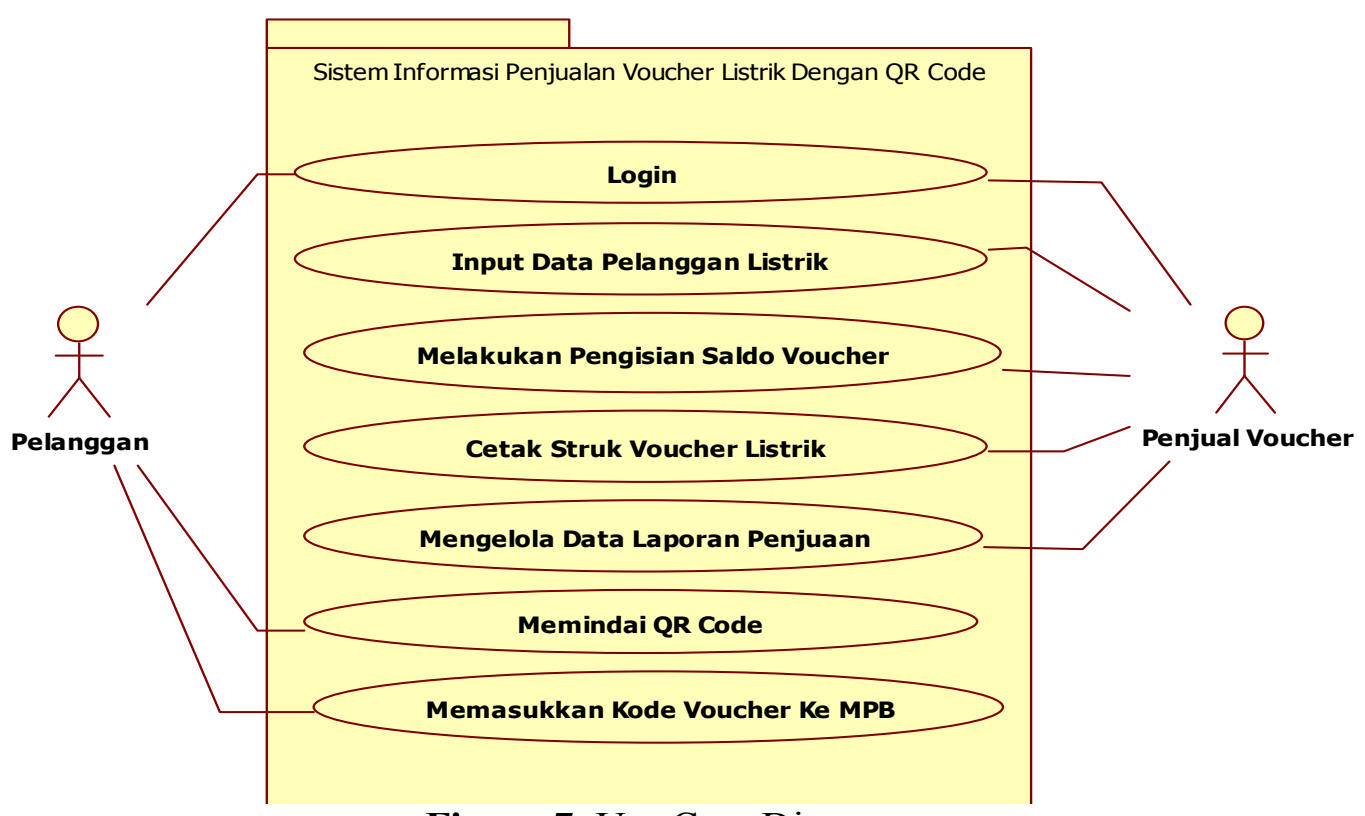

Figure 7. Use Case Diagram

\subsection{System Design}

Design stages is done after the stage of system analysis. This stage describes the design of software systems and mobile web applications. The design phase consists of designing Entity Relational Diagram (ERD), application architecture, and class diagrams.

\subsubsection{Entity Relational Diagram (ERD) Design}

Entity Relationship Diagram is made based on observation of business process sales of prepaid electricity voucher in several sales outlets and also based on analysis of some documents obtained from the sales outlet. The ERD is broken down to a few tables that are fare table, clients table, payment table and user table. While password reset and migration table is a table that is built inLaravel framework. Customers list is taken from dummy database. In actual condition, customers list will be taken from PLN customers database. The PLN customer's database is simulated by using dummy database. Based on four tables as mentioned earlier, it can be described Entity Relational Diagram (ERD) of prepaid electricity voucher using QR code technology as in figure 8.

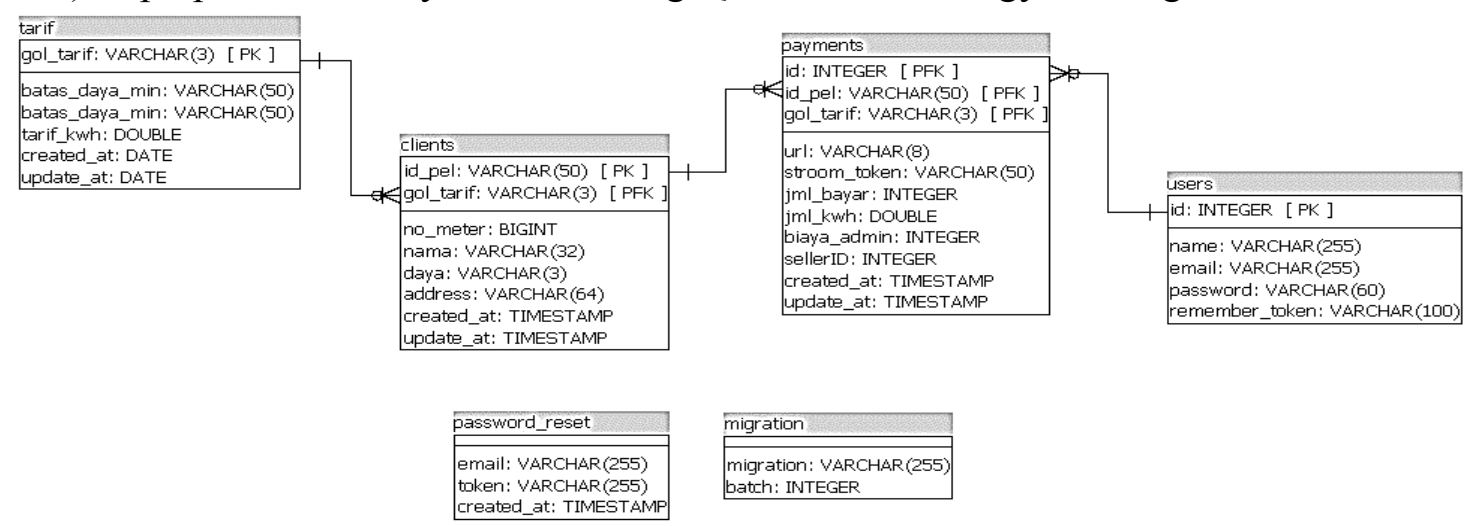

Figure 8. Entity Relational Diagram (ERD) 


\section{JURNAL INFORMATIKA Vol. 11, No. 2 Juli 2017}

\subsubsection{Aplication Architecture Design}

The term architecture refers to the design of an application that described where the components of the system are placed and how they communicate [7]. In this research, application of prepaid electricity voucher sales made by using Model-View-Controller (MVC) architecture. MVC architecture has been proven can be used to build projects more effectively. This was done by sorting the components between the Model, View and Controller on parts of the project [8]. MVC architecture allows separation between the model and the view and allows multiple views using the same model. As a result, the component model of an application can be implemented, tested, and maintained easily, because all access to the model runs through this component [9]. MVC architecture of these applications can be seen in Figure 9

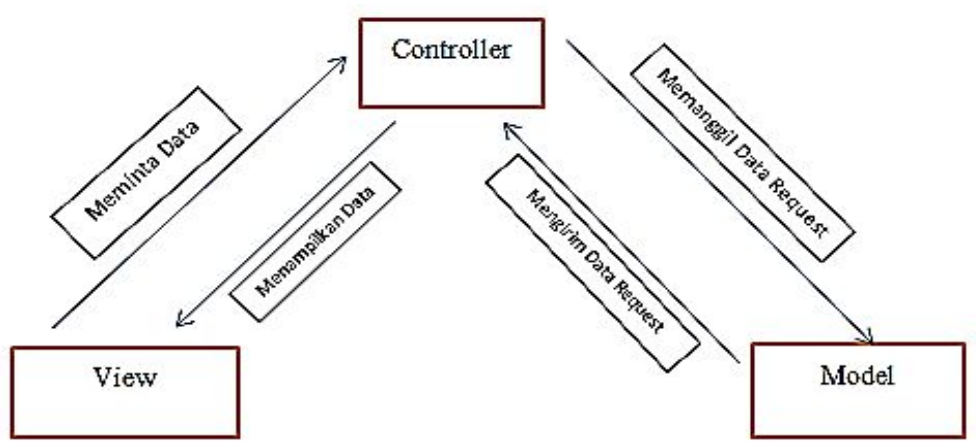

Figure 9. MVC Architecture

\subsubsection{Class Diagram Design}

Class diagram is a diagram that describeclasses involves in an application. Class Diagram is designed based on the MVC architecture described earlier. Class diagrams of this application displays only controller class and class models while the view component does not have class. There are two (2) class controllers, clientscontroller and paymentscontroller. As for the model class, there are three (3) types of clients, payments and tariffs. Class clientscontroller only relate to the model class clients, while class

paymentscontroller class associated with all models. Details of diagram class can be seen in Figure 10. 


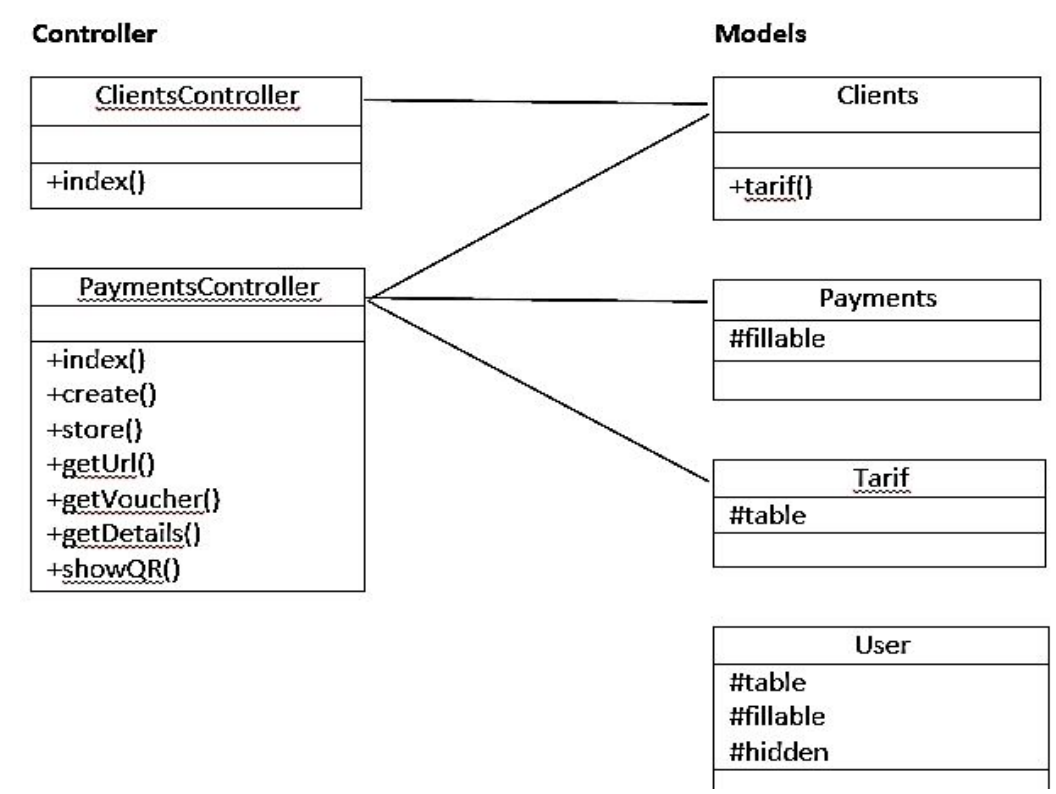

Figure 10. Class Diagram

\section{IMPLEMENTATION AND TESTING}

Implementation stage is the stage of applicationconstruction. System design that already design in previous step is implemented by using programming language to create application. The implementation stage produces a web-based application using PHP, JavaScript, jQuery uses a MySQL database and mobile applications developed using the tools Basic4ndroid.

\subsection{Implementation Limitation}

There are several limitations in implementation stage. Those limitations are:

a. Database server used in this application is open source software DBMS MySQL.

b. Programming language used in development stage is PHP and javascript for web based application.

c. Web application is build on Laravel Framework.

d. Mobile application is developed by using Rapid Application Development tool (RAD) Basic4android.

e. JSON is used as data format to transfer data from web to mobile applications.

f. Web applications built using the concept of Object Oriented Programming (OOP) with MVC architecture

\subsection{Construction}

Construction of web application is follow the convention of Laravel Framework. Figure 11 shows partial source code of paymentsController class that serve as liason between view and model.

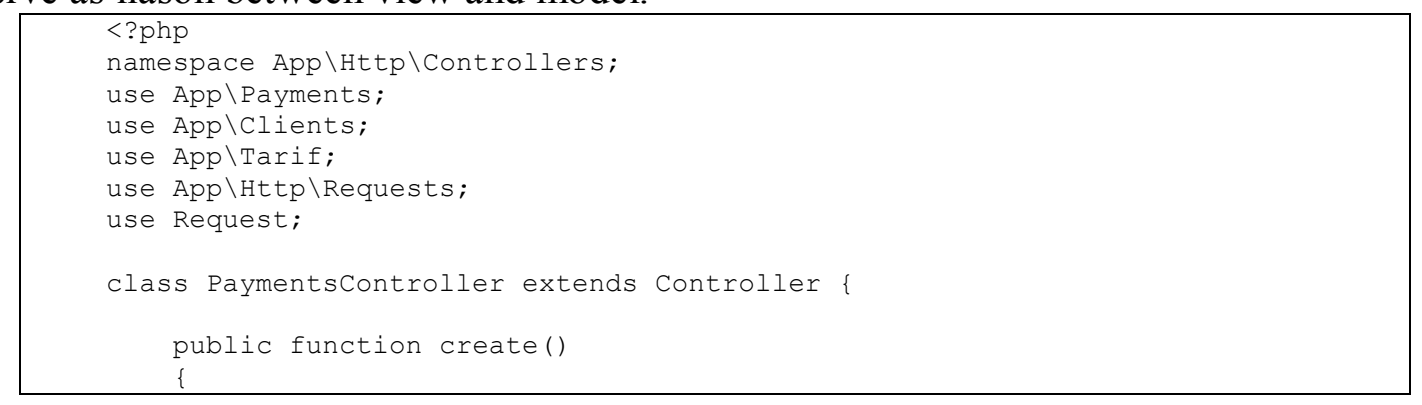




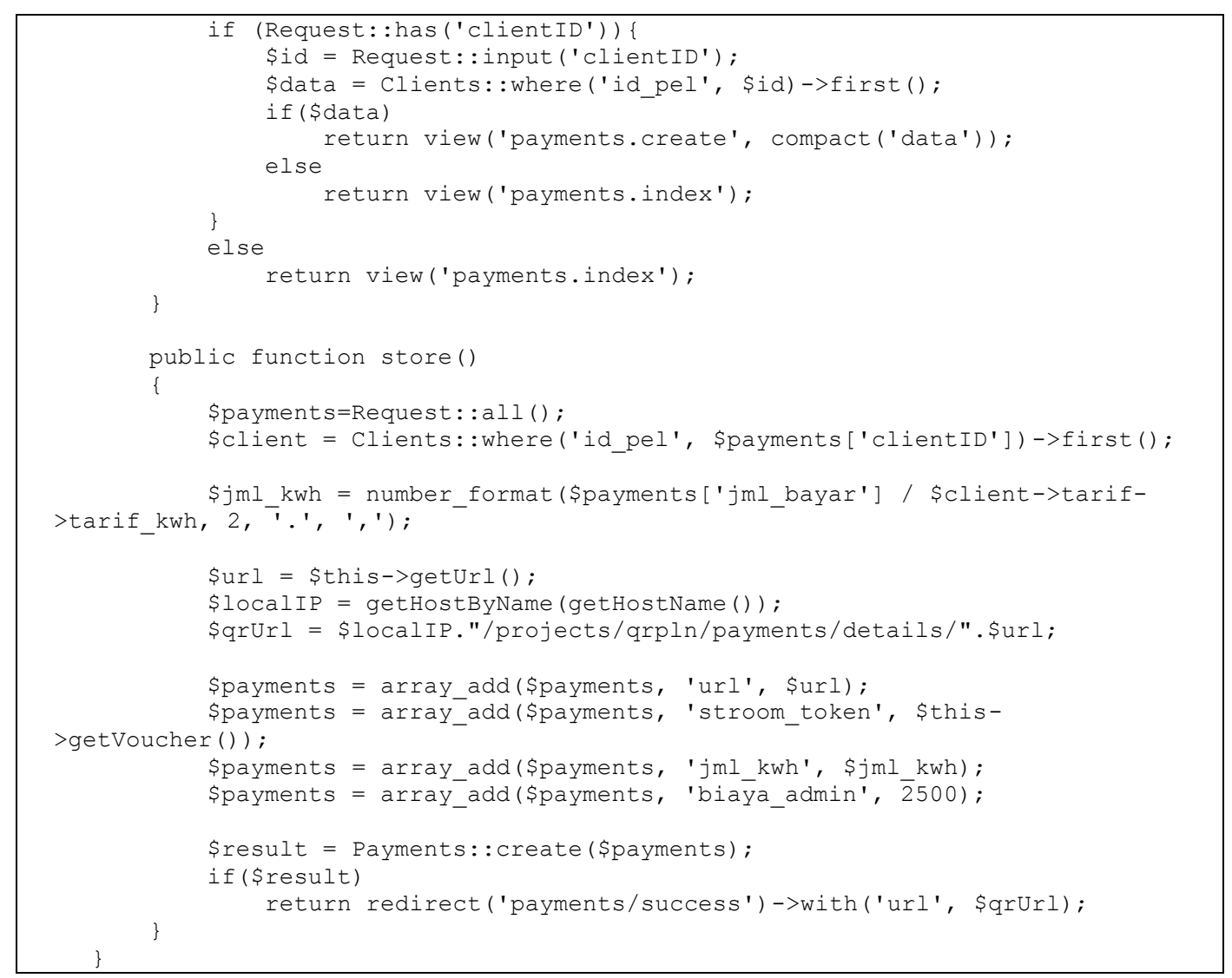

\section{Figure 11.ClientsController Class script}

Those code is algorithm to store payment form customer and generate QR Code for customer. The QR Code itself generated by using service provided by http://qrickit.com.

\subsection{User Interface Implementation}

User Interface implementation consists of web based application and mobile application. Here Here are some of the user interface implementation of applications that are built:

\subsubsection{Web application user interface}

Web application user interface is consisted of user interface to input and check the customer data and the nominal of prepaid electrical voucher bought by the customer. Customer account number is entered to form on web application, then the system will check the account number is entered. If it is a valid account number, then system will display another customer data input form to fill in nominal of voucher purchased. User interface of web application to fill in nominal of voucher can be seen in Figure 12 


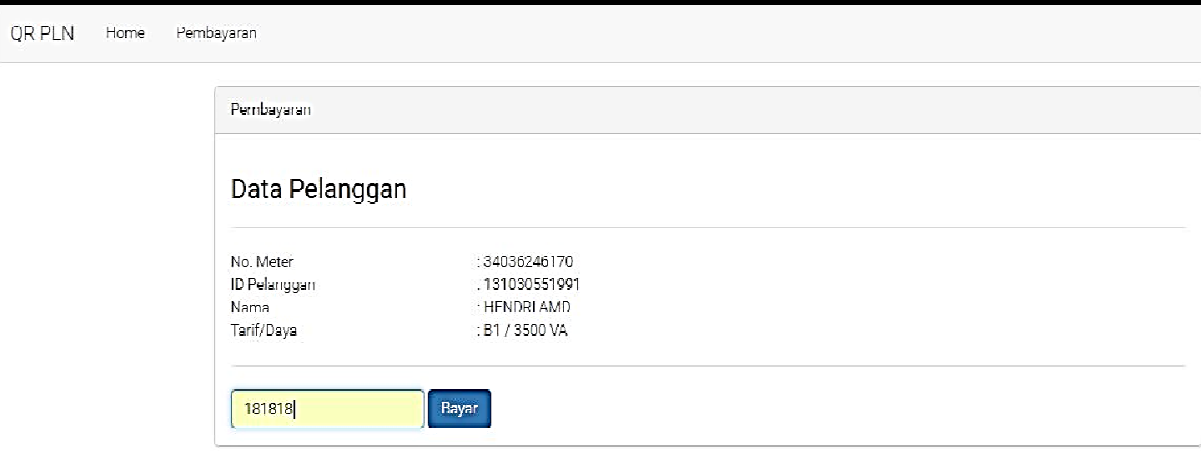

Figure 12. Antar Muka Pengisian Nominal Voucher Listrik

After nominal of voucher inputted, system will display the QR Code. Mobile application will display information about customer info and 20-digit voucher number based on this QR Code. This QR will only be able read by developed mobile application. This mobile application will only be used by registered users by using provided username and password. This application secure the information about token. Even the prepaid electricity voucher receipt has gone or broken, customer still able to retrieve the token by using application mobile.

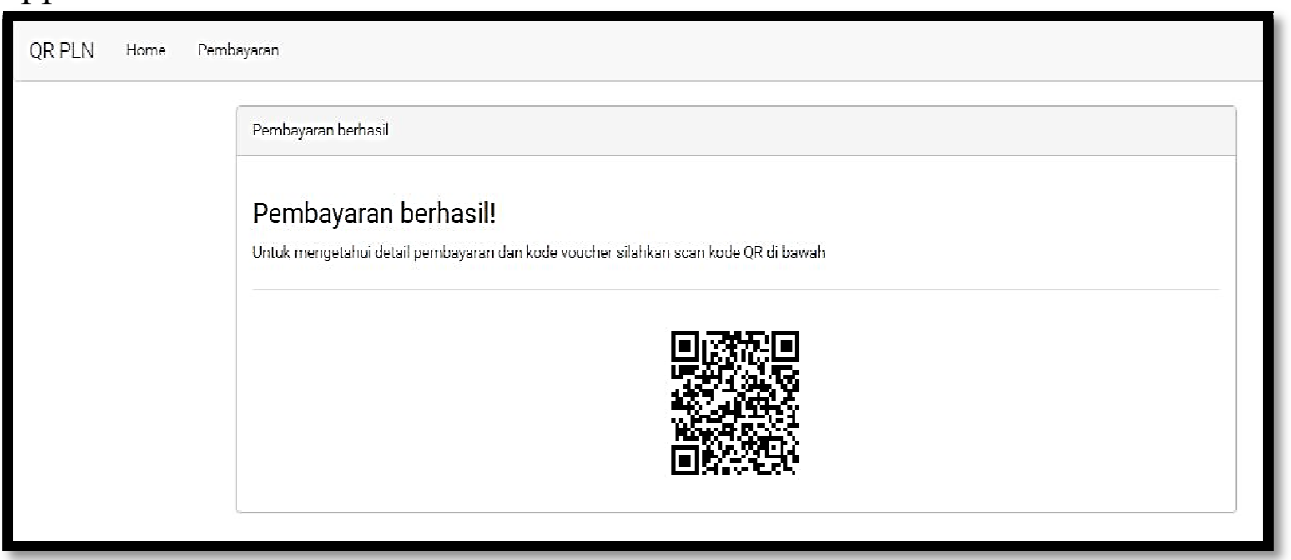

Figure 13. QR Code Output on Web Application

\subsubsection{Mobile Application User Interface}

After the Web application to produce QR Code, then android application read the QR Code. Figure 14 is a display of the results generated QR Code through the interface of mobile applications. This mobile application is delivered to subscribers with special username and password, so that each customer can only use the mobile app QR Code reader after outlet operator provide mobile application with username and password to the customer. 


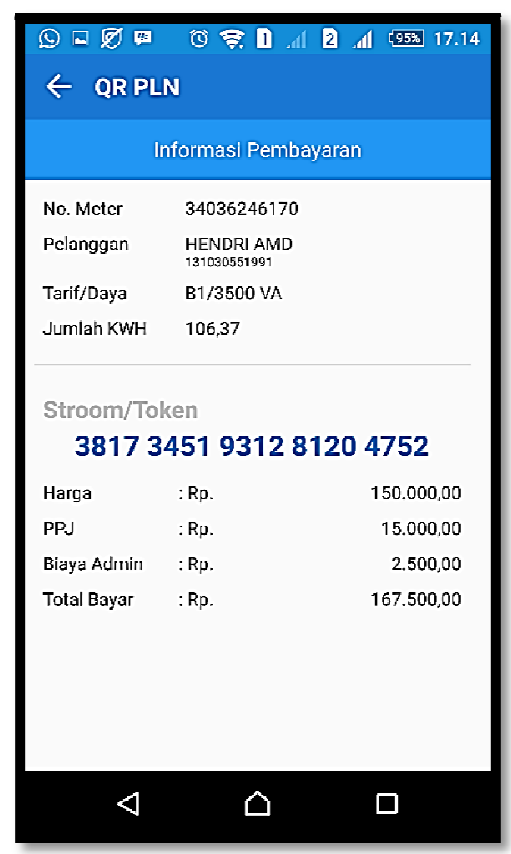

Gambar 14. Mobile application user interface.

\subsection{System Testing}

The testing phase of the system is a process of checking whether the developed application meets the requirements that have been set on previous stage. Testing is done by using blackbox methodology that focuses on the functional requirements of the application. Black box testing methods used for testing web and mobile applications.

\subsubsection{Testing item}

There are several functional tested on developed application. Those item can be seen on Table 1

Table 1. Testing Items

\begin{tabular}{|c|l|c|l|}
\hline No & Testing Item & Tested Application & Tested Process \\
\hline 1 & User Data & Web & Register user \\
\hline 2 & Outlet operator Login & Web & User verification \\
\hline 3 & Customer Login & Mobile & User verification \\
\hline 4 & $\begin{array}{l}\text { Customer account number } \\
\text { and payment checking }\end{array}$ & Web & $\begin{array}{l}\text { Search } \\
\text { Input }\end{array}$ \\
\hline 5 & Scanning QR Code & Mobile & Scanning \\
\hline
\end{tabular}

\subsubsection{Test Cases and Test Results}

Tests conducted on system are focused on item presented in Table 1. Testing methodlolgy that being used is blackbox testing. Blackbox testing is testing based on fungsional by checking output based on provided input. Testing is held in 2 condition, normal condition and alternative condition. For example, testing on checking customer account and payment checking, testing is done in 2 condition. First condition is done by filling in valid customer 
account number. Second condition is done by filling in invalid customer account number into application form. The test results are shown in Table 2.

Table 2. Pengujian Pengecekan Nomor Rekening dam Pembayaran

\begin{tabular}{|l|l|}
\hline \multicolumn{2}{|l|}{ Test case and test result (normal condition) } \\
\hline Customer account number and payment checking \\
\hline Input & Valid customer account number \\
\hline Expected output & System shows customer's information \\
\hline Observation & $\begin{array}{l}\text { System shows information about customer then show form to } \\
\text { fill in nominal of voucher. }\end{array}$ \\
\hline Result & Accepted \\
\hline Test case and test result (alternative condition) \\
\hline Customer account number and payment checking \\
\hline Input & Invalid customer account number \\
\hline Expected output & System shows notification \\
\hline Observation & $\begin{array}{l}\text { System shows notification and form of voucher nominal is not } \\
\text { displayed. }\end{array}$ \\
\hline Result & Accepted \\
\hline
\end{tabular}

Based on Table 2, when outlet operator fills in form with valid customer account number, application shows customer's information and alsow show payment form as seen in Figure 15. Thereafter nominal payments filled in to the form system will display QR Code as transaction receipt as seen in Figure 16. It is concluded that customer checking and payment checking feature can be accepted. Tha same testing procedure is implemented to other functional requirements. Testing results show that all functional requirements are work as expected.

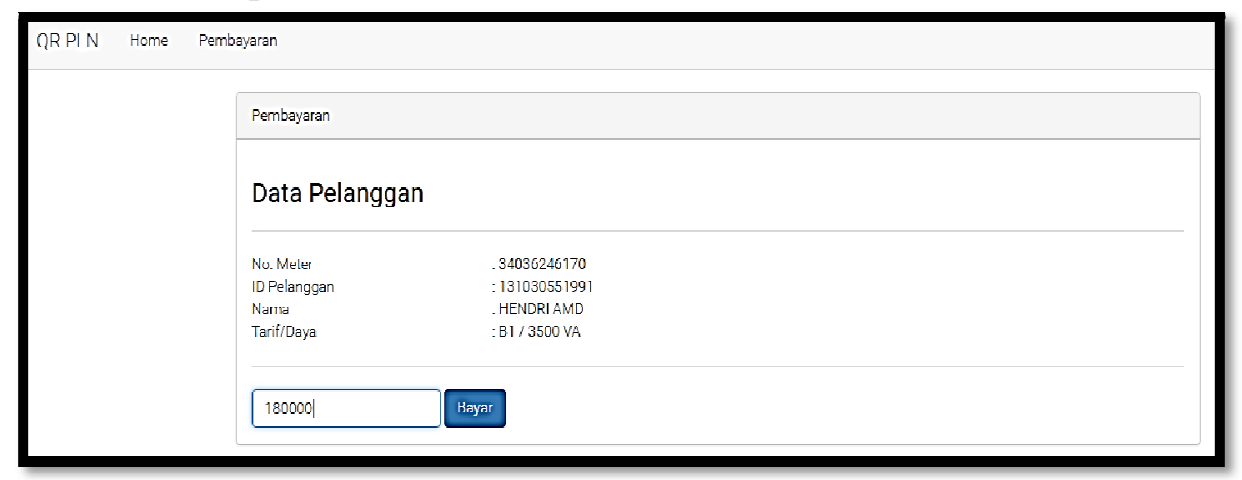

Figure 15. Payment Form

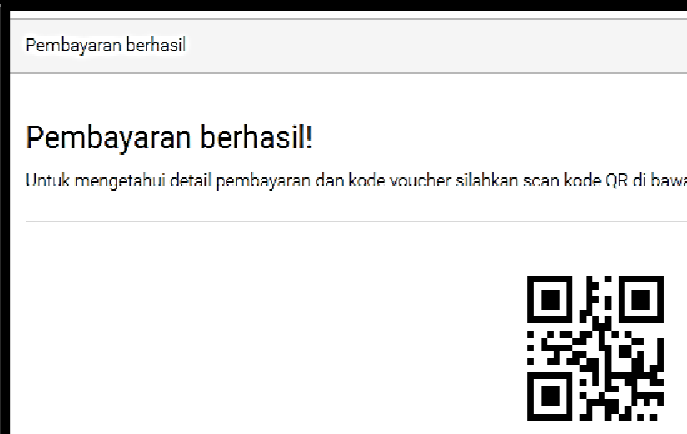

Figure 16. QR Code as transaction receipt 


\section{JURNAL INFORMATIKA Vol. 11, No. 2 Juli 2017}

\section{CONCLUSION}

Sales application of prepaid electricity voucher had been developed. The development process is started from analysis until testing. This application is developed by using Object Oriented Programming (OOP) concept that implemented on Laravel Framework. Architecture of this system is Model-View Controller (MVC) that also already defined in Laravel Framework. Mobile application of this system is developed by using Basic4Android. The database used in this application is MySQL. Based on testing result, this application fulfills all functional requirement that already defined on analysis stage. By using this application, transaction of prepaid electricity voucher can be done safe and secure because all data transformed into QR Code, so it is stored in the customer's smartphone and can not be misused by others and.

\section{REFERENCES}

[1] Listrik. Listrik Prabayar. http://www.pln.co.id/blog/apa-itu-listrik-prabayar Accessed on 15 March 2016, 21.17 WIB.

[2] Nugraha M P, Munir R. 2011. Pengembangan Aplikasi QR Code Generator dan QR Code Reader dari Data Berbentuk Image.Konferensi Nasional Informatika-KNIF 2011.

[3] Rahayu, Yeni Dewi, dkk. 2006. Pembuatan Aplikasi Pembacaan Quick Response Code Menggunakan Perangkat Mobile Berbasis J2ME Untuk Identifikasi Suatu Barang. Surabaya. Politeknik Elektronika Negeri Surabaya Institut Teknologi Sepulu November.

[4] Hidayat. 2011. Sekilas Tentang QR Code.http://duniahidayat.blogspot.co.id/2011/11/sekilas-tentang-qr-code.html, Accessed on 15 March 201621.40 WIB

[5] I. Sommerville. 2011. Software Engineering Ninth Edition, Boston: Person Education.

[6] Juharsa, Jujun. (2009). Perancangan Sistem Informasi Penerimaan Siswa Online SMP Negeri 27 Bandung. Skripsi pada Universitas Komputer Indonesia Bandung: Tidak diterbitkan.

[7] Luthfi, Emha Taufiq. (2006). Pemrograman client Server. Yogyakarta: Sekolah Tinggi Manajemen Informatika Dan Komputer "AMIKOM".

[8] Wardhana, Tedi. 2009. Pengamanan Database yang di Implementasikan ke dalam Arsitektur MVC menggunakan Hibernate Framework.Tugas Akhir pada Universitas Gunadarma. Jakarta: Tidak Diterbitkan.

[9] Hidayat, Arief \& Surarso, Bayu. 2012. Penerapan Arsitektur Model View Controller (MVC) Dalam Rancangan Bangun Sistem Kuis Online Adaptif. Yogyakarta: Seminar Nasional Teknologi Informasi dan Komunikasi 2012 (SENTIKA 2012) 